\title{
Editorial: Actinobacteria, a Source of Biocatalytic Tools
}

\author{
Dirk Tischler ${ }^{1 *}$, Willem J. H. van Berkel ${ }^{2}$ and Marco W. Fraaije ${ }^{3}$ \\ ${ }^{1}$ Microbial Biotechnology, Biology and Biotechnology, Ruhr University Bochum, Bochum, Germany, ${ }^{2}$ Laboratory of \\ Biochemistry, Wageningen University \& Research, Wageningen, Netherlands, ${ }^{3}$ Molecular Enzymology, University of \\ Groningen, Groningen, Netherlands
}

Keywords: actinomycetes, secondary metabolites, high GC genetics, novel biocatalysts, extremophile actinobacteria, biotechnology, biocatalysis, germination

\section{Editorial on the Research Topic}

Actinobacteria, a Source of Biocatalytic Tools

\section{ACTINOBACTERIA: ANCIENT PHYLUM WITH LARGE BIOTECHNOLOGICAL POTENTIAL STILL TO BE UNCOVERED}

OPEN ACCESS

Edited by:

Marc Strous,

University of Calgary, Canada

Reviewed by:

Dmitry A. Rodionov,

Sanford Burnham Prebys Medical

Discovery Institute, United States

*Correspondence:

Dirk Tischler

dirk.tischler@rub.de,

dirk-tischler@email.de

Specialty section:

This article was submitted to Microbial Physiology and Metabolism,

a section of the journal

Frontiers in Microbiology

Received: 25 January 2019

Accepted: 28 March 2019

Published: 16 April 2019

Citation:

Tischler D, van Berkel WJH and Fraaije MW (2019) Editorial:

Actinobacteria, a Source of Biocatalytic Tools.

Front. Microbiol. 10:800.

doi: 10.3389/fmicb.2019.00800
Actinobacteria (Actinomycetes) represent one of the largest and most diverse phyla among the Bacteria. The characteristics and phylogeny of actinobacteria have been well-described throughout the years (Anteneh and Franco; Embley et al., 1994; Stackebrandt et al., 1997a,b; Stach and Bull, 2005; Stackebrandt and Schumann, 2006; Ventura et al., 2007; Gao and Gupta, 2012; Goodfellow, 2012a,b; Schrempf, 2013; Lawson, 2018; Lewin et al., 2016). Still actinobacteria are hotspots for discovery of new biomolecules and enzyme activities, fueling an active field of research. The remarkable diversity is displayed by various lifestyles, distinct morphologies, a wide spectrum of physiological and metabolic activities, as well as genetics.

Most actinobacteria have a high GC-content (ranging from $51 \%$ to over $70 \%$ ) and belong to Gram-positive or Gram-variable type microbes (Stackebrandt and Schumann, 2006; Ventura et al., 2007; Lawson, 2018). Many species are well-known for their large genomes, which may be of linear style, as in case of rhodococci, or circular (Ventura et al., 2007; Sen et al., 2014; Lewin et al., 2016). Many also harbor linear megaplasmids as a kind of genetic storage device (König et al., 2004; Medema et al., 2010; Wagenknecht et al., 2010; Bottacini et al., 2015). These plasmids often encode special metabolic features such as secondary metabolite synthetic machineries or alternative degradation pathways. However, a number of representatives comprise smaller genomes such as some Bifidobacteria, Corynebacteria, Mycobacteria, and Propionibacteria species (Ventura et al., 2007; Lewin et al., 2016). Interestingly, smaller genomes are often encountered in pathogens or in those, which live in ecological niches. The smallest actinobacterial genomes can be found among Tropheryma, which is known as the Whipple's disease microbe (Bentley et al., 2003; Raoult et al., 2003). Gene redundancy or genes encoding for closely related enzymes are frequently reported and in most cases the evolutionary history or a functional role remains enigmatic (McLeod et al., 2006; Tischler et al., 2009, 2010, 2013; Roberts et al., 2011; Riebel et al., 2012; Gröning et al., 2014; Riedel et al., 2015a,b; Nguyen et al., 2017; Chen et al., 2018; Gran-Scheuch et al.). In this context horizontal gene transfer was found to play a major role in the genome fluidity of actinobacteria (Ventura et al., 2007). However, this seems not to be true for all actinobacteria or limited to some features such as secondary metabolism as discussed for Streptomyces and Rhodococcus, respectively (McLeod et al., 2006; Lewin et al., 2016). 
The large actinobacterial genomes and megaplasmids provide access to an impressive number of potential biocatalysts and pathways (Lewin et al., 2016). A few examples of novel biocatalysts linked to gene redundancy are cited above, but still more truly novel enzymes or pathways await elucidation. Actinobacteria are well-known for their biotechnological potential which is exemplarily described for amino acid producing Corynebacteria (Poetsch et al., 2011; Goldbeck et al.; Pérez-García et al.), secondary metabolite producing Streptomyces (Niu et al., 2016; Senges et al., 2018), pathogenic targets as Nocardia and Mycobacteria (Cosma et al., 2003; Wilson, 2012), carotenoid building Micrococcus strains (Rostami et al., 2016), acid fermenting Propionibacteria (Rabah et al., 2017), health and food related Bifidobacterium strains (Lawson, 2018), rubber degrading Gordonia species (Linos et al., 1999; Heine et al., 2018), and organic pollutant degrading rhodococci (McLeod et al., 2006; Kim et al., 2018) among others.

In many cases individual pathways can be exploited for the production of valuable products, or enzymes can be recombinantly produced and exploited for biocatalysis. Even some genetic tools to work directly in actinobacteria have been successfully used as for example in Corynebacterium (Nešvera and Pátek, 2011). Recently some additional systems have been established to create e.g., Kocuria and Rhodococcus hosts (Montersino et al.; Toda and Itoh). The first system allowed actually to express genes of various origins in Kocuria, whereas the Rhodococcus system was used for identification of the natural phospholipid ligand of a monooxygenase. During the last decade more and more genomes have been sequenced and made available for data mining and become accessible by state-of-the-art genomic manipulation methods. Novel pathways and enzymes are frequently described from actinobacteria as a result of the progress in various omics approaches and high-throughput methods. Except for novel pathways or enzymes, genome analyses have revealed that actinobacteria also employ rather unique cofactors, such as the $\mathrm{F}_{420}$ cofactor (Selengut and Haft, 2010; Greening et al., 2016; Nguyen et al., 2017; Ney et al.). With respect to biocatalysis and derived applications a number of recent studies can be mentioned. These comprise whole-cell systems (Oelschlägel et al., 2015; Okamoto et al., 2017; de Carvalho, 2017; Goldbeck et al.; Yin et al.) enzymatic cascades (Kara et al., 2015; $\mathrm{Ni}$ et al., 2016; Zimmerling et al., 2017), structure-function relationships (Riebel et al., 2012; Montersino et al., 2013; Riedel et al., 2015a,b; Sucharitakul et al., 2016; Scholtissek et al., 2017; Scholtissek et al.) as well as mechanistic insights (Greening et al.; Ney et al.; Westphal et al.).

Secondary metabolite production is of industrial interest and here especially Streptomyces has to be mentioned which provides access to antibiotics as well as siderophores (Medema et al., 2010; Čihák et al.; Botas et al.; López-García et al.; Senges et al., 2018; Suárez Moreno et al.). Secondary metabolite production is frequently investigated either on a regulatory level (Botas et al.) or via metabolomics (Senges et al., 2018) and of course within biotechnological studies. It was found that the lifestyle and the development stage seem to be crucial for secondary metabolism. Spore formation among Streptomyces is such a specialized development stage and of importance for cell regulatory processes, but also with respect to applications (Bobek et al.). Further, some regulatory elements are solely present among actinobacteria and need to be functionally tested (Koepff et al.; López-García et al.; Šetinová et al.). Growth limiting conditions (Fe-, N-, S-limitations or presence of toxic compounds/elements) are often used to overproduce target compounds and among those the secondary metabolites siderophores (Retamal-Morales et al., 2017, 2018b; Senges et al., 2018) and biosurfactants (Kügler et al., 2015; Retamal-Morales et al., 2018a) can be mentioned.

Actinobacteria also harbor extremophile branches, which become more and more attractive for biotechnological investigations (Shivlata and Satyanarayana, 2015). Examples include antimicrobial compound producers as many Streptomyces spp. (Radhakrishnan et al., 2007; Xue et al., 2013), siderophore producing strains as Thermobifida fusca (Dimise et al., 2008) and Thermocrispum agreste (Heine et al., 2017), and many rhizosphere specialists with various interactions toward plants, fungi and/or other bacteria (Palaniyandi et al., 2013). Besides the above described actinobacteria mainly derived from soil, also other habitats and ecological niches are explored and successfully conquered by various actinobacteria. Among those interesting resources for biotechnology are present (Shivlata and Satyanarayana, 2015).

In conclusion, it becomes obvious that the large and diverse group of actinobacteria is of interest from different perspectives such as general microbiology, ecology, phylogeny, biochemistry, and regulation, environmental concerns, pathogenicity as well as biotechnology. Still there are new members being discovered that belong to this phylum or reclassifications occur according to new findings with respect to morphology and phylogeny. The increasing amount of data from various omics fields allows us to uncover more and more properties which can be of use for various (biotechnological) purposes. We believe that the potential of actinobacteria for biotechnology was only touched lightly thus far: there is more to be uncovered!

\section{AUTHOR CONTRIBUTIONS}

DT, WB, and MF drafted this editorial together and approved it prior submission.

\section{ACKNOWLEDGMENTS}

The authors thank the Frontiers Team for support during handling of the Research Topic and all Contributors for providing insides into their research. 


\section{REFERENCES}

Bentley, S. D., Maiwald, M., Murphy, L. D., Pallen, M. J., Yeats, C. A., Dover, L. G., et al. (2003). Sequencing and analysis of the genome of the Whipple's disease bacterium Tropheryma whipplei. Lancet 361, 637-644. doi: 10.1016/S0140-6736(03)12597-4

Bottacini, F., O'Connell Motherway, M., Casey, E., McDonnell, B., Mahony, J., Ventura, M., et al. (2015). Discovery of a conjugative megaplasmid in Bifidobacterium breve. Appl. Environ. Microbiol. 81, 166-176. doi: 10.1128/AEM.02871-14

Chen, B. S., Médici, R., van der Helm, M. P., van Zwet, Y., Gjonaj, L., van der Geest, R., et al. (2018). Rhodococcus strains as source for ene-reductase activity. Appl. Microbiol. Biotechnol. 102, 5545-5556. doi: 10.1007/s00253-018-8984-7

Cosma, C. L., Sherman, D. R., and Ramakrishnan, L. (2003). The secret lives of the pathogenic mycobacteria. Annu. Rev. Microbiol. 57, 641-676. doi: 10.1146/annurev.micro.57.030502.091033

de Carvalho, C. C. (2017). Whole cell biocatalysts: Essential workers from Nature to the industry. Microb. Biotechnol. 10, 250-263. doi: 10.1111/1751-7915.12363

Dimise, E. J., Widboom, P. F., and Bruner, S. D. (2008). Structure elucidation and biosynthesis of fuscachelins, peptide siderophores from the moderate thermophile Thermobifida fusca. Proc. Natl. Acad. Sci. U.S.A. 105, 15311-15316. doi: 10.1073/pnas.0805451105

Embley, T. M., Hirt, R. P., and Williams, D. M. (1994). Biodiversity at the molecular level: the domains, kingdoms and phyla of life. Phil. Trans. R. Soc. B 345, 21-33. doi: 10.1098/rstb.1994.0083

Gao, B., and Gupta, R. S. (2012). Phylogenetic framework and molecular signatures for the main clades of the phylum actinobacteria. Microbiol. Mol. Biol. Rev. 76, 66-112. doi: 10.1128/MMBR.05011-11

Goodfellow, M. (2012a). "Class I. Actinobacteria," in Bergey's Manual of Systematic Bacteriology, eds M. Goodfellow, P. Kampfer, H.-J. Busse, M. E. Trujillo, K.-I. Suzuki, W. Ludwig, and B. Whitman (New York, NY: Springer), 34-45.

Goodfellow, M. (2012b). "Phylum XXVI. Actinobacteria phyl. nov," in Bergey's Manual of Systematic Bacteriology, eds M. Goodfellow, P. Kampfer, H.-J. Busse, M. E. Trujillo, K.-I. Suzuki, W. Ludwig, and B. Whitman (New York, NY: Springer), 33-2028.

Greening, C., Ahmed, F. H., Mohamed, A. E., Lee, B. M., Pandey, G., Warden, A. C., et al. (2016). Physiology, biochemistry, and applications of F420and Fo-dependent redox reactions. Microbiol. Mol. Biol. Rev. 80, 451-493. doi: 10.1128/MMBR.00070-15

Gröning, J. A., Eulberg, D., Tischler, D., Kaschabek, S. R., and Schlömann, M. (2014). Gene redundancy of two-component (chloro)phenol hydroxylases in Rhodococcus opacus 1CP. FEMS Microbiol. Lett. 361: 68-75. doi: $10.1111 / 1574-6968.12616$

Heine, T., Mehnert, M., Schwabe, R., and Tischler, D. (2017). Thermochelin, a hydroxamate siderophore from Thermocrispum agreste DSM 44070. Solid State Phenomena 262, 505-508. doi: 10.4028/www.scientific.net/SSP.262.501

Heine, T., Zimmerling, J., Ballmann, A., Kleeberg, S. B., Rückert, C., Busche, T., et al. (2018). On the enigma of glutathione-dependent styrene degradation in Gordonia rubripertincta CWB2. Appl. Environ. Microbiol. 84:e00154-e00118. doi: 10.1128/AEM.00154-18

Kara, S., Schrittwieser, J. H., Gargiulo, S., Ni, Y., Yanase, H., Opperman, D. J., et al. (2015). Complete enzymatic oxidation of methanol to carbon dioxide: Towards more eco-efficient NAD(P)H regeneration systems. Adv. Synth. Catal. 357, 1687-1691. doi: 10.1002/adsc.201500173

Kim, D., Choi, K. Y., Yoo, M., Zylstra, G. J., and Kim, E. (2018). Biotechnological potential of Rhodococcus biodegradative pathways. J. Microbiol. Biotechnol. 28, 1037-1051. doi: 10.4014/jmb.1712.12017

König, C., Eulberg, D., Gröning, J. A., Lakner, S., Seibert, V., Kaschabek, S. R., et al. (2004). A linear megaplasmid, p1CP, carrying the genes for chlorocatechol catabolism of Rhodococcus opacus 1CP. Microbiology 150, 3075-3087. doi: 10.1099/mic.0.27217-0

Kügler, J. H., Le Roes-Hill, M., Syldatk, C., and Hausmann, R. (2015). Surfactants tailored by the class actinobacteria. Front. Microbiol. 6:212. doi: $10.3389 /$ fmicb.2015.00212

Lawson, P. A. (2018). "The phylum actinobacteria," in The Bifidobacteria and Related Organisms. Biology, Taxonomy, Applications, eds P. Mattarelli, B. Biavati, W. H. Holzapfel, and B. J. B Wood (London: Elsevier; Academic Press), 1-8. doi: 10.1016/B978-0-12-805060-6.00001-6
Lewin, G. R., Carlos, C., Chevrette, M. G., Horn, H. A., McDonald, B. R., Stankey, R. J., et al. (2016). Evolution and ecology of actinobacteria and their bioenergy applications. Annu. Rev. Microbiol. 70, 235-254. doi: 10.1146/annurev-micro-102215-095748

Linos, A., Steinbüchel, A., Spröer, C., and Kroppenstedt, R. M. (1999). Gordonia polyisoprenivorans sp. nov., a rubber-degrading actinomycete isolated from an automobile tyre. Int. J. Syst. Bacteriol. 49, 1785-1791. doi: 10.1099/00207713-49-4-1785

McLeod, M. P., Warren, R. L., Hsiao, W. W., Araki, N., Myhre, M., Fernandes, C., et al. (2006). The complete genome of Rhodococcus sp. RHAl provides insights into a catabolic powerhouse. Proc. Natl. Acad. Sci. U.S.A. 103, 15582-15587. doi: $10.1073 /$ pnas.0607048103

Medema, M. H., Trefzer, A., Kovalchuk, A., van den Berg, M., Müller, U., Heijne, W., et al. (2010). The sequence of a 1.8-mb bacterial linear plasmid reveals a rich evolutionary reservoir of secondary metabolic pathways. Genome Biol. Evol. 12, 212-224. doi: 10.1093/gbe/evq013

Montersino, S., Orru, R., Barendregt, A., Westphal, A. H., van Duijn, E., Mattevi, A., et al. (2013). Crystal structure of 3-hydroxybenzoate 6-hydroxylase uncovers lipid-assisted flavoprotein strategy for regioselective aromatic hydroxylation. J. Biol. Chem. 288, 26235-26245. doi: 10.1074/jbc.M113.479303

Nešvera, J., and Pátek, M. (2011). Tools for genetic manipulations in Corynebacterium glutamicum and their applications. Appl. Microbiol. Biotechnol. 90, 1641-1654. doi: 10.1007/s00253-011-3272-9.

Nguyen, Q. T., Trinco, G., Binda, C., Mattevi, A., and Fraaije, M. W. (2017). Discovery and characterization of an F420-dependent glucose-6-phosphate dehydrogenase (Rh-FGD1) from Rhodococcus jostii RHA1. Appl. Microbiol. Biotechnol. 101, 2831-2842. doi: 10.1007/s00253-016-8038-y

Ni, Y., Fernández-Fueyo, E., Gomez Baraibar, A., Ullrich, R., Hofrichter, M., Yanase, H., et al. (2016). Peroxygenase-catalyzed oxyfunctionalization reactions promoted by the complete oxidation of methanol. Angew. Chem. Int. Ed. Engl. 55, 798-801. doi: 10.1002/anie.201507881

Niu, G., Chater, K. F., Tian, Y., Zhang, J., and Tan, H. (2016). Specialised metabolites regulating antibiotic biosynthesis in Streptomyces spp. FEMS Microbiol. Rev. 40, 554-573. doi: 10.1093/femsre/fuw012

Oelschlägel, M., Kaschabek, S. R., Zimmerling, J., Schlömann, M., and Tischler, D. (2015). Co-metabolic formation of substituted phenylacetic acids by styrenedegrading bacteria. Biotechnol. Rep. 6, 20-26. doi: 10.1016/j.btre.2015.01.003

Okamoto, D. N., Ferrari, V. B., Lago, J. H. G., de Melo, I. S., and Vasconcellos, S. P. (2017). Actinomycetes as tools for biotransformations of lignans. Biomed. J. Sci. Tech. Res. 1, 1-3. doi: 10.26717/BJSTR.2017.01.000448

Palaniyandi, S. A., Yang, S. H., Zhang, L., and Suh, J. W. (2013). Effects of actinobacteria on plant disease suppression and growth promotion. Appl. Microbiol. Biotechnol. 97, 9621-9636. doi: 10.1007/s00253-013-5206-1

Poetsch, A., Haussmann, U., and Burkovski, A. (2011). Proteomics of corynebacteria: from biotechnology workhorses to pathogens. Proteomics 11, 3244-3255. doi: 10.1002/pmic.201000786

Rabah, H., Rosa do Carmo, F. L., and Jan, G. (2017). Dairy propionibacteria: versatile probiotics. Microorganisms 5:E24. doi: $10.3390 /$ microorganisms5020024

Radhakrishnan, M., Balaji, S., and Balagurunathan, R. (2007). Thermotolerant actinomycetes from Himalayan Mountain - antagonistic potential, characterization and identification of selected strains. Malaysian Appl. Biol. 36, 59-65.

Raoult, D., Ogata, H., Audic, S., Robert, C., Suhre, K., Drancourt, M., et al. (2003). Tropheryma whipplei Twist: a human pathogenic Actinobacteria with a reduced genome. Genome Res. 13, 1800-1809. doi: 10.1101/gr.1474603

Retamal-Morales, G., Heine, T., Tischler, J. S., Erler, B., Gröning, J. A. D., Kaschabek, S. R., et al. (2018a). Draft genome sequence of Rhodococcus erythropolis $\mathrm{B} 7 \mathrm{~g}$, a biosurfactant producing actinobacterium. J. Biotechnol. 280, 38-41. doi: 10.1016/j.jbiotec.2018.06.001

Retamal-Morales, G., Mehnert, M., Schwabe, R., Tischler, D., Schlömann, M., and Levicán, G. J. (2017). Genomic characterization of the arsenictolerant actinobacterium, Rhodococcus erythropolis S43. Solid State Phenomena 262, 660-663. doi: 10.4028/www.scientific.net/SSP.262.660

Retamal-Morales, G., Mehnert, M., Schwabe, R., Tischler, D., Zapata, C., Chávez, R., et al. (2018b). Detection of arsenic-binding siderophores in arsenictolerating actinobacteria by a modified CAS assay. Ecotoxicol. Environ. Saf. 157, 176-181. doi: 10.1016/j.ecoenv.2018.03.087 
Riebel, A., Dudek, H. M., de Gonzalo, G., Stepniak, P., Rychlewski, L., and Fraaije, M. W. (2012). Expanding the set of rhodococcal BaeyerVilliger monooxygenases by high-throughput cloning, expression and substrate screening. Appl. Microbiol. Biotechnol. 95, 1479-1489. doi: 10.1007/s00253-011-3823-0

Riedel, A., Heine, T., Westphal, A. H., Conrad, C., Rathsack, P., van Berkel, W. J., et al. (2015a). Catalytic and hydrodynamic properties of styrene monooxygenases from Rhodococcus opacus 1CP are modulated by cofactor binding. AMB Express 5, 30. doi: 10.1186/s13568-015-0112-9

Riedel, A., Mehnert, M., Paul, C. E., Westphal, A. H., van Berkel, W. J., and Tischler, D. (2015b). Functional characterization and stability improvement of a 'thermophilic-like' ene-reductase from Rhodococcus opacus 1CP. Front. Microbiol. 6:1073. doi: 10.3389/fmicb.2015.01073

Roberts, J. N., Singh, R., Grigg, J. C., Murphy, M. E., Bugg, T. D., and Eltis, L. D. (2011). Characterization of dye-decolorizing peroxidases from Rhodococcus jostii RHA1. Biochemistry 50, 5108-5119. doi: 10.1021/bi200427h

Rostami, H., Hamedi, H., and Yolmeh, M. (2016). Some biological activities of pigments extracted from Micrococcus roseus (PTCC 1411) and Rhodotorula glutinis (PTCC 5257). Int. J. Immunopathol. Pharmacol. 29, 684-695. doi: $10.1177 / 0394632016673846$

Scholtissek, A.,., Tischler, D.,., Westphal, A. H., van Berkel, W. J. H., and Paul, C. E. (2017). Old Yellow Enzyme-catalysed asymmetric hydrogenation: linking family roots with improved catalysis. Catalysts 7:130. doi: 10.3390/catal 7050130

Schrempf, H. (2013). Actinobacteria within soils: capacities for mutualism, symbiosis and pathogenesis. FEMS Microbiol. Lett. 342, 77-78. doi: 10.1111/1574-6968.12147

Selengut, J. D., and Haft, D. H. (2010). Unexpected abundance of coenzyme F(420)-dependent enzymes in Mycobacterium tuberculosis and other actinobacteria. J. Bacteriol. 192, 5788-5798. doi: 10.1128/JB.00425-10

Sen, A., Daubin, V., Abrouk, D., Gifford, I., Berry, A. M., and Normand, P. (2014). Phylogeny of the class actinobacteria revisited in the light of complete genomes. The orders 'Frankiales' and Micrococcales should be split into coherent entities: proposal of Frankiales ord. nov., Geodermatophilales ord. nov., Acidothermales ord. nov. and Nakamurellales ord. nov. Int. J. Syst. Evol. Microbiol. 64, 3821-3832. doi: 10.1099/ijs.0.063966-0

Senges, C. H. R., Al-Dilaimi, A., Marchbank, D. H., Wibberg, D., Winkler, A., Haltli, B., et al. (2018). The secreted metabolome of Streptomyces chartreusis and implications for bacterial chemistry. Proc. Natl. Acad. Sci. U.S.A. 115, 2490-2495. doi: 10.1073/pnas.1715713115

Shivlata, L., and Satyanarayana, T. (2015). Thermophilic and alkaliphilic actinobacteria: biology and potential applications. Front. Microbiol. 6:1014. doi: $10.3389 /$ fmicb. 2015.01014

Stach, J. E., and Bull, A. T. (2005). Estimating and comparing the diversity of marine actinobacteria. Antonie Van Leeuwenhoek 87, 3-9. doi: 10.1007/s10482-004-6524-1

Stackebrandt, E., Rainey, F. A., and Ward-Rainey, N. L. (1997a). Proposal for a new hierarchic classification system, Actinobacteria classis nov.. Int. J. Syst. Evol. Microbiol. 47, 479-491.

Stackebrandt, E., and Schumann, P. (2006). "Introduction to the taxonomy of actinobacteria," in The Prokaryotes, eds M. Dworkin, S. Falkow, E. Rosenberg, K.-H. Schleifer, and F. Stackebrandt (New York, NY: Springer), 297-321.
Stackebrandt, E., Sproer, C., Rainey, F. A., Burghardt, J., Päuker, O., and Hippe, H. (1997b). Phylogenetic analysis of the genus Desulfotomaculum: evidence for the misclassification of Desulfotomaculum guttoideum and description of Desulfotomaculum orientis as Desulfosporosinus orientis gen. nov., comb. nov.. Int. J. Syst. Evol. Microbiol. 47, 1134-1139.

Sucharitakul, J., Medhanavyn, D., Pakotiprapha, D., van Berkel, W. J., and Chaiyen, P. (2016). Tyr217 and His213 are important for substrate binding and hydroxylation of 3-hydroxybenzoate 6-hydroxylase from Rhodococcus jostii RHA1. FEBS J. 283, 860-881. doi: 10.1111/febs. 13636

Tischler, D., Eulberg, D., Lakner, S., Kaschabek, S. R., van Berkel, W. J., and Schlömann, M. (2009). Identification of a novel self-sufficient styrene monooxygenase from Rhodococcus opacus 1CP. J. Bacteriol. 191, 4996-5009. doi: 10.1128/JB.00723-10

Tischler, D., Kermer, R., Gröning, J. A., Kaschabek, S. R., van Berkel, W. J., and Schlömann, M. (2010). StyA1 and StyA2B from Rhodococcus opacus 1CP: a multifunctional styrene monooxygenase system. J. Bacteriol. 192, 5220-5227. doi: 10.1128/JB.00723-10

Tischler, D., Niescher, S., Kaschabek, S. R., and Schlömann, M. (2013). Trehalose phosphate synthases otsal and otsa2 of Rhodococcus opacus 1CP. FEMS Microbiol. Lett. 342, 113-122. doi: 10.1111/1574-6968.12096

Ventura, M., Canchaya, C., Tauch, A., Chandra, G., Fitzgerald, G. F., Chater, K. F., et al. (2007). Genomics of actinobacteria: tracing the evolutionary history of an ancient phylum. Microbiol. Mol. Biol. Rev. 71, 495-548. doi: 10.1128/MMBR.00005-07

Wagenknecht, M., Dib, J. R., Thürmer, A., Daniel, R., Farías, M. E., and Meinhardt, F. (2010). Structural peculiarities of linear megaplasmid, pLMA1, from Micrococcus luteus interfere with pyrosequencing reads assembly. Biotechnol. Lett. 32, 1853-1862. doi: 10.1007/s10529-0100357-y

Wilson, J. W. (2012). Nocardiosis: updates and clinical overview. Mayo Clin. Proc. 87, 403-407. doi: 10.1016/j.mayocp.2011.11.016

Xue, L., Xue, Q., Chen, Q., Lin, C., Shen, G., and Zhao, J. (2013). Isolation and evaluation of rhizosphere actinomycetes with potential application for biocontrol of Verticillium wilt of cotton. Crop Prot. 43, 231-240. doi: 10.1016/j.cropro.2012.10.002

Zimmerling, J., Tischler, D., Großmann, C., Schlömann, M., and Oelschlägel, M. (2017) Characterization of aldehyde dehydrogenases applying an enzyme assay with in situ formation of phenylacetaldehydes. Appl. Biochem. Biotechnol. 182, 1095-1107. doi: 10.1007/s12010-016-2384-1

Conflict of Interest Statement: The authors declare that the research was conducted in the absence of any commercial or financial relationships that could be construed as a potential conflict of interest.

Copyright (c) 2019 Tischler, van Berkel and Fraaije. This is an open-access article distributed under the terms of the Creative Commons Attribution License (CC BY). The use, distribution or reproduction in other forums is permitted, provided the original author(s) and the copyright owner(s) are credited and that the original publication in this journal is cited, in accordance with accepted academic practice. No use, distribution or reproduction is permitted which does not comply with these terms. 